\title{
Wykorzystanie urządzeń hydrostatycznych w układach napędowych spalinowych pojazdów trakcyjnych typu autobus szynowy
}

\begin{abstract}
Artykut jest poświęcony układom napędowym stosowanym od wielu lat w pojazdach szynowych pomocniczych $i$ specjalnych. Zaprezentowano $w$ nim ogólne opisy uktadów napędowych $i$ wykorzystanych $w$ nich urzadzeniach hydrostatycznych $w$ wózkach motorowych, pociagach sieciowych $i$ do utrzymania sieci trakcyjnej oraz w pojazdach szynowo-drogowych. Wykorzystujac doświadczenia zdobyte $w$ projektowaniu układów napędowych pojazdów pomocniczych i specjalnych przedstawiono propozycje wykorzystania urzadzeń hydrostatycznych $w$ budowie układów napędowych możliwych do zastosowania $w$ autobusach szynowych przeznaczonych do obstugi ruchu pasażerskiego na liniach drugorzędnych. W zakończeniu przedstawiono przewidywane korzyści wynikajace z zastosowania układów napędowych.
\end{abstract}

\section{Wstęp}

Ostatnie lata charakteryzują się ożywieniem na rynku przewozów pasażerskich na liniach lokalnych, podmiejskich i regionalnych. Prowadzone są obecnie próby reaktywowania przewozów na liniach nieużywanych od wielu lat, które wymagać będą szczegółowych przeglądów i napraw w szczególności torów i podtorza, peronów, wiat i ewentualnie budynków stacyjnych oraz układów związanych ze sterowaniem ruchem kolejowym i bezpieczeństwem ruchu.

Do prób przejęcia tych linii i wprowadzenia do ruchu pociagów pasażerskich obsługiwanych najczęściej lekkimi pojazdami trakcyjnymi (autobusami szynowymi) dążą zarówno prywatni operatorzy kolejowi jak i działające na rynku przewozowym i powstające koleje regionalne finansowane $\mathrm{z}$ funduszy marszałkowskich.

Przewoźnicy ci będą zapewne zainteresowani zakupem tanich, prostych w obsłudze i niezawodnych lekkich pojazdów o uproszczonej konstrukcji gwarantujących jednocześnie bezpieczeństwo eksploatacji dla przewożonych pasażerów i obsługi.

Obecnie w kraju eksploatowane są lekkie pojazdy trakcyjne (autobusy szynowe) w których stosowane sa następujące konfiguracje układów napędowych [1]:

- spalinowe z przekładnią hydrauliczną (hydromechaniczną)

- spalinowo-elektryczne z przekładnią elektryczną

- elektryczne.

Zdaniem autora należałoby rozważyć wdrożenia do eksploatacji również innych prostych i tanich lekkich pojazdów szynowych mających swój pierwowzór w autobusach drogowych wyposażonych w układy napędowe oparte na urządzeniach hydrostatycznych stosowanych ponadto $\mathrm{w}$ pociagach sieciowych, ma- szynach torowych, wózkach motorowych oraz w niektórych konstrukcjach pojazdów szynowo-drogowych.

Pozwoliłoby to również na zmniejszenie ceny pojazdu oraz obniżenie kosztów eksploatacyjnych. Do rozważenia jest również wprowadzenie tego typu układów dla autobusów szynowych wycofywanych z eksploatacji.

W dalszej części artykułu postaramy się przedstawić koncepcje układów napędowych w oparciu o lekkie silniki spalinowe, pompy i silniki hydrostatyczne jako alternatywa do stosowanych obecnie układów napędowych autobusów szynowych.

\section{Układy napędowe hydrostatyczne pojazdów pomocniczych, specjalnych oraz pojazdów szynowo-drogowych}

Układy napędów hydrostatycznych są stosowane przede wszystkim do napędu pojazdów pomocniczych i specjalnych takich jak wózki motorowe, pociagi sieciowe, pojazdy do utrzymania torów, pojazdy do utrzymania sieci i oświetlenia oraz pojazdy szynowodrogowe. Należy również zaznaczyć, że napędy hydrostatyczne stosowane są $\mathrm{z}$ powodzeniem $\mathrm{w}$ zagranicznych lekkich lokomotywach spalinowych przeznaczonych do prac manewrowych oraz prowadzenia pociagów osobowych (najczęściej w ruchu turystycznym) w trudnych terenach górskich i podgórskich.

Obecnie w kraju napędy hydrostatyczne zastosowane zostały w pojazdach pomocniczych i specjalnych produkowanych przez Zakład Pojazdów Szynowych w Stargardzie Szczecińskim $[8,9.10,11]$ oraz w pojeździe szynowo-drogowym przeznaczonym do 
oczyszczania infrastruktury tramwajowej opracowanym i wykonanym na bazie samochodu Iveco Eurocargo Model 140E18W przez Instytut Pojazdów Szynowych ,Tabor” w Poznaniu [4].

Identyczne napędy w pojazdach szynowo-drogowych zostały zastosowane w samochodach Iveco produkowanych przez firmy „Astride” Costamasnaga S.A. i „Sivć” S.A. (Włochy) oraz w samochodach firmy Mercedes wykonanych przez Spezialfahrzeugaufbaut und Kabeltechnick GmbH z Halle (Niemcy) oraz Stadler - Fahrzeuge A G Bussnang (Szwajcaria) [3].

\subsection{Układ napędowy wózka motorowego WM- 15H.00}

Układ napędowy wózka motorowego typu WM-15.00 składa się z silnika spalinowego, przystawki napędowej, przekładni osiowej oraz hydraulicznego układu napędu jazdy [10].

Wysokoprężny silnik spalinowy firmy Deutz o mocy $240 \mathrm{~kW}$ napędza poprzez koło zamachowe i sprzęgło podatne zespół pomp hydraulicznych wytwarzających ciśnienie w obwodach hydrauliki jazdy oraz hydrauliki roboczej pojazdu.

Przekładnie osiowe zamontowane na obu zestawach kołowych są przekładniami dwustopniowymi kątowymi - pierwszy stopień tworzy para kół zębatych stożkowych, drugi natomiast para kół zębatych walcowych. Przekładnia jest zawieszona na ramie wózka za pośrednictwem elastycznego ciagła.

Układ hydrauliczny napędu jazdy składa się z:

- wysokociśnieniowej pompy tłokowo-osiowej o zmiennym wydatku i zmiennym kierunku tłoczenia

- wysokociśnieniowych tłokowych silników hydraulicznych o zmiennej chłonności oleju, mocowanych za pośrednictwem przystawki napędowej do przekładni osiowej

- chłodnicy powietrznej $\mathrm{z}$ wentylatorem napędzanym oraz zbiornika oleju

- sterownika elektronicznego umożliwiającego w sposób automatyczny sterowanie wydatkiem pompy hydraulicznej z zależności od obciążenia oraz prędkości jazdy wózka

- bloku zaworowego zabezpieczającego silnik spalinowy przed nadmiernym i niekontrolowanym wzrostem obrotów podczas hamowania hydraulicznego .

Sterowanie jazdą wózka może być automatyczne lub ręczne.

Zastosowany w wózku układ biegowy jest układem typowym dla wagonów towarowych dwuosiowych i umożliwia eksploatację pojazdu z prędkościami do 80 $\mathrm{km} / \mathrm{h}$.

Widok ogólny wózka motorowego oraz układu napędowego przedstawiono na rys. 1 . a)

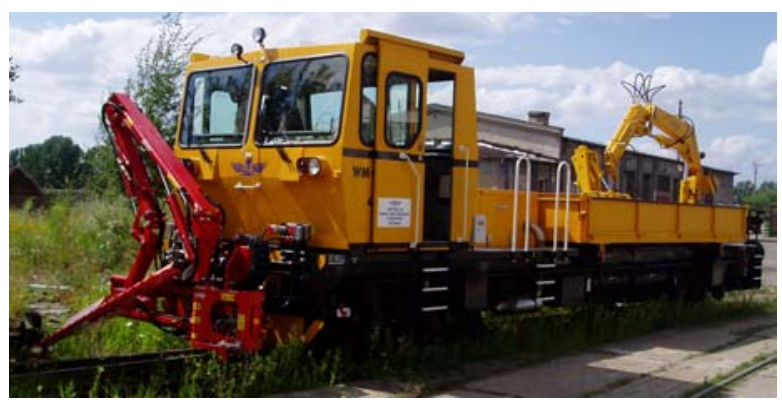

b)

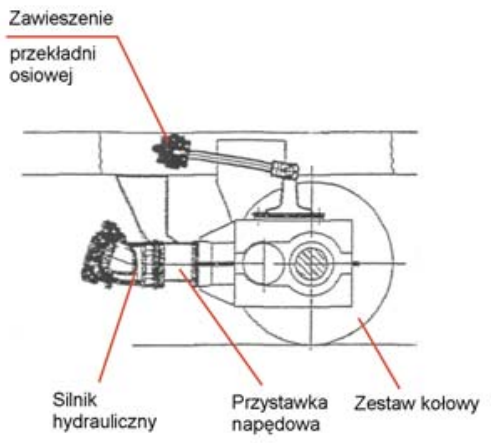

Rys. 1 - Wózek motorowy typu WM-15H.00 (a) wraz z układem napędowym (b)

\subsection{Układ napędowy pociągu sieciowego PS-00. M/B i pojazdu do utrzymania sieci i oświetle- nia PUSiO.05}

Hydrostatyczny układ napędowy pociągów sieciowych typu PS-00.M/B oraz pojazdu do utrzymania sieci i oświetlenia typu PUSiO.05 składa się z silnika spalinowego, przekładni osiowej oraz hydraulicznego układu napędu jazdy.

W pojeździe typu PS-00.M/B zastosowano silnik spalinowy wysokoprężny firmy Deutz typu TCD 2015 V 064V o mocy $240 \mathrm{~kW}$ natomiast $\mathrm{w}$ pojeździe PUSiO.05 silnik spalinowy firmy Deutz typu TCD 2013 o mocy $181 \mathrm{~kW}[8,11]$.

W obu pojazdach zabudowano ten sam typ przekładni osiowej typu P-35. Jest to dwustopniowa przekładnia zębata o kołach walcowych, zębach prostych oraz osiach równoległych i służy do przeniesienia napędu $\mathrm{z}$ silnika hydrostatycznego na koła jezdne oraz do rozłączenia napędu na czas transportu pojazdów w składzie pociagu lub holowania.

Hydrauliczny układ napędu jazdy składa się z pompy hydraulicznej, dwóch silników hydrostatycznych, chłodnicy i zbiornika oleju oraz elektronicznego sterownika i jest identyczny jak dla wózka motorowego typu WM-15H.00.

Sterowanie jazdą może odbywać się w sposób automatyczny, ręczny oraz za pośrednictwem fal radiowych. Układ jezdny obu pojazdów jest zbudowany $z$ dwóch zestawów kołowych napędnych, które prowadzone są przez układ prowadników wzdłużnych. Układ zawieszenia jest jednostopniowy wykorzystujący sprężyny śrubowe oraz tłumiki hydrauliczne.

Widok ogólny pojazdów PS-00.M/B i PUSiO.05 oraz zastosowanego w nich układu napędowego przedstawiono na rys. 2 . 
a)

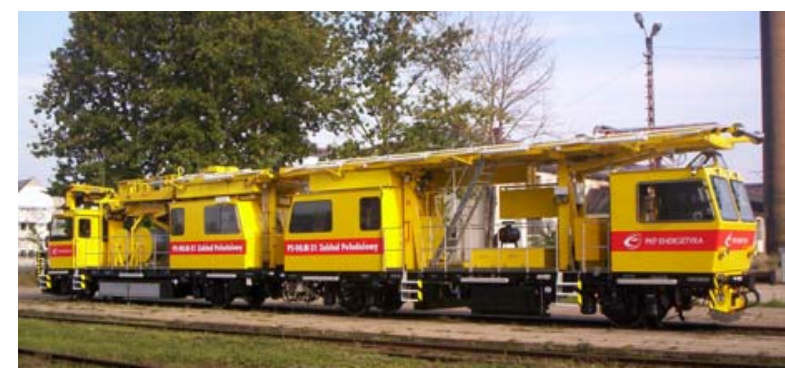

b)

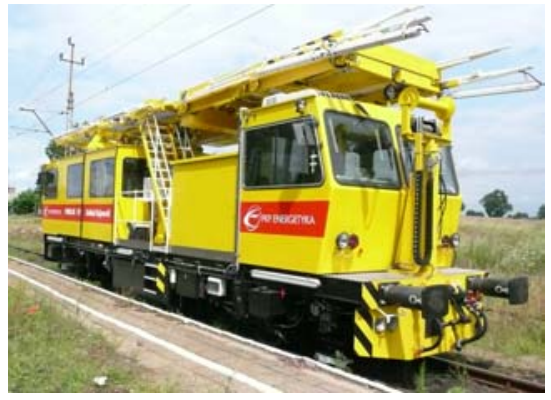

Zawieszenie

przekładni osiowej

c)

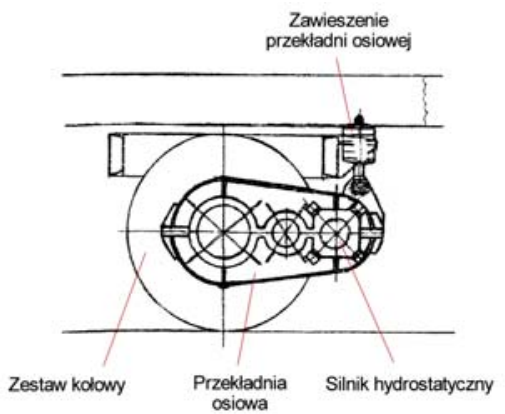

Rys. 2 - Pociąg sieciowy PS-00.M/B (a) i pojazd do utrzymania sieci i oświetlenia PUSiO. (b)

oraz zastosowany w nich układ napędowy (c)

\subsection{Układ napędowy uniwersalnego ciągnika szy- nowego UCS-40.00}

Układ napędowy uniwersalnego ciąnika szynowego typu UCS-40.00 tworzą [9]:

- wysokoprężny silnik spalinowy firmy Caterpillar typu C18 ACERT o mocy $522 \mathrm{~kW}$

- przekładnie osiowe dwustopniowe, zębate o kołach walcowych, zębach prostych i osiach równoległych (identyczne jak dla pojazdów PS00.M/B i PUSiO.05)

- hydrauliczny układ napędu jazdy składający się z dwóch pomp hydraulicznych, czterech silników hydrostatycznych, dwóch chłodnic oleju, zbiornika oleju oraz elektronicznego sterownika jazdy.

Układ biegowy ciagnika tworzą dwa dwuosiowe wózki typu $27 \mathrm{TN}$ i $27 \mathrm{TNa}$ zaprojektowane specjalnie dla maszyn torowych.

Widok ogólny uniwersalnego ciagnika szynowego typu UCS-40.00 oraz zastosowanego w nim układu napędowego przedstawiono na rys. 3 . a)

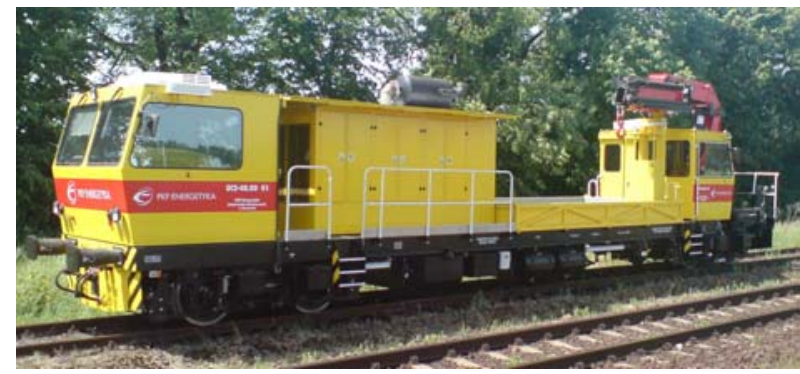

b)

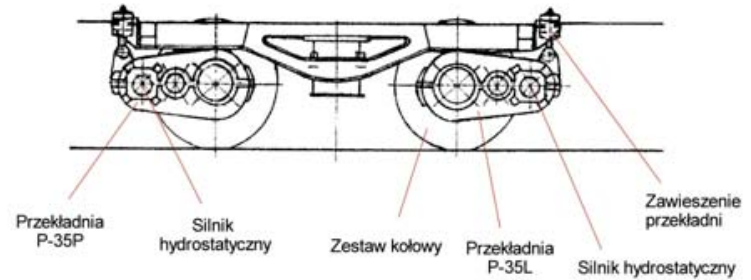

Rys. 3 - Uniwersalny ciągnik szynowy typu UCS-40.00 (a) i zastosowany w nim układ napędowy (b)

\subsection{Układ napędowy pojazdu szynowo-drogowego TC do oczyszczania infrastruktury tramwajo- wej}

Układ napędowy pojazdu szynowo-drogowego typu TC do oczyszczania infrastruktury tramwajowej składa się z pompy hydrostatycznej o zmiennej wydajności i zmiennym kierunku tłoczenia napędzanej z silnika spalinowego o mocy $134 \mathrm{~kW}$ bazowego samochodu Iveco Eurocargo [4]. Pompa hydrostatyczna napedza osiowe silniki hydrostatyczne pracujące w układzie szeregowym [5]. Silniki hydrostatyczne (bez hamulca, $\mathrm{z}$ hamulcem) przykręcane są bezpośrednio do wahaczy. Napęd z silników hydrostatycznych jest przekazywany na rolkę jezdną za pośrednictwem specjalnej tarczy łożyskowanej w wahaczu.

Widok ogólny pojazdu szynowo-drogowego wraz z widokiem na przedni układ napędowy przedstawiono na rys. 4.

a)

Rys. 4 - Pojazd szynowodrogowy typu

TC do oczyszczania infrastruktury tramwajowej

(a) oraz jego przedni układ napędowy (b)

b)
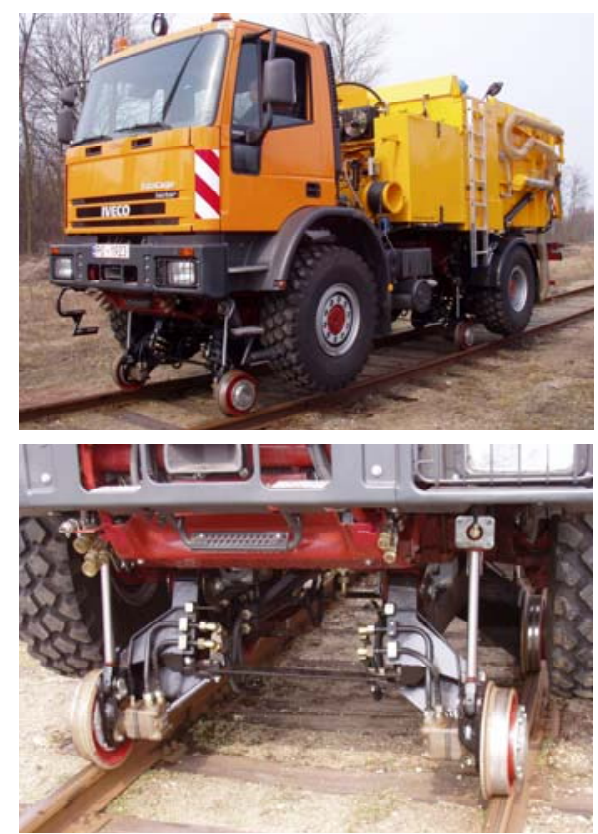
Prędkości eksploatacyjne przedstawionych pojazdów są niewielkie i nie przekraczają $80 \mathrm{~km} / \mathrm{h}$. Nie oznacza to, że w innej konfiguracji nie będzie można jej zwiększyć do około $100 \div 110 \mathrm{~km} / \mathrm{h}$, a więc wystarczającej dla lekkich pojazdów szynowych przeznaczonych do eksploatacji $\mathrm{w}$ ruchu pasażerskim na liniach drugorzędnych $[6,7]$.

\section{Koncepcje układów napędowych $z$ wykorzy- staniem urządzeń hydrostatycznych}

Eksploatacja układów napędowych hydrostatycznych w pojazdach pomocniczych pozwala na „optymizm” $\mathrm{w}$ ich zastosowaniu również w napędach lekkich pojazdów, zwanych autobusami szynowymi, przeznaczonych przede wszystkim do wykorzystania w ruchu pasażerskim na liniach drugorzędnych i wydzielonych.

Wprowadzenie nowego typu napędu może dać następujące korzyści [2]:

- obniżenia masy pojazdów w wyniku rezygnacji z ostrych wymagań wytrzymałościowych

- uproszczenia układów pociagowo-zderznych (np. jak dla tramwajów)

- wycofania z pojazdów części urządzeń związanych $\mathrm{z}$ bezpieczeństwem ruchu

- rezygnacja ze skomplikowanych urządzeń rejestrujących

- uproszczenia układu hamulca (możliwe zastosowanie hamulca pneumatycznego lub hydraulicznego)

- uproszczenia układów sterowania i diagnostyki (w tym rezygnacja ze sterowania wielokrotnego).

Nowe układy napędowe byłyby oparte o urządzenia (pompy i silniki) hydrostatyczne, które znalazły zastosowanie również $\mathrm{w}$ pomocniczych maszynach torowych i sieciowych $[3 \div 11]$.

Pierwszy i drugi z układów zaprezentowanych na rys. 5 i 6 jest układem tradycyjnym z jedną pompą i dwoma silnikami hydrostatycznymi możliwym do zastosowania w lekkim pojeździe szynowym (jednoczłonowym autobusie szynowym) z wózkami dwuosiowymi.

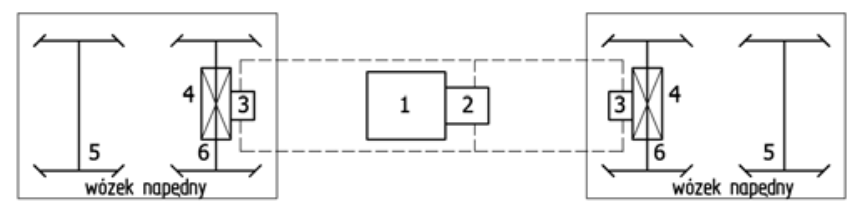

Rys. 5 -Układ napędowy z jedną pompą i dwoma silnikami hydrostatycznymi szybkoobrotowymi o zmiennej chłonności: 1 silnik spalinowy; 2 - pompa hydrostatyczna; 3 - silnik

hydrostatyczny; 4 - przekładnia osiowa; 5 - zestaw kołowy toczny; 6 - zestaw kołowy napędny
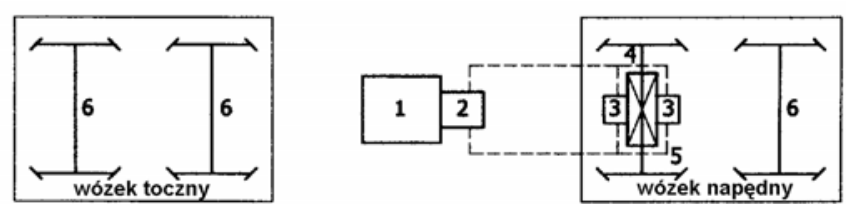

Rys. 6 -Układ napędowy z jedną pompą i dwoma silnikami hydrostatycznymi szybkoobrotowymi o zmiennej chłonności (napęd na jeden zestaw kołowy) 1 - silnik spalinowy; 2 - pompa hydrostatyczna; 3 - silnik hydrostatyczny; 4 - przekładnia osiowa; 5 - zestaw kołowy napędny; 6 - zestaw kołowy toczny.

Natomiast trzeci (o konfiguracji podobnej dla pojazdów szynowo-drogowych) wymagać będzie przebudowy wózków trakcyjnych i zastosowania kół (rezygnacja z całkowitych osi) z indywidualnym napędem.

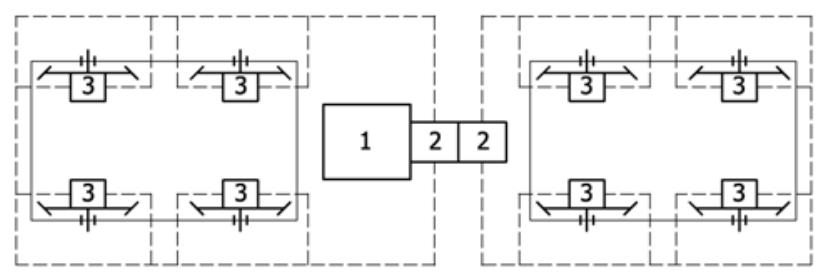

Rys. 7 -Układ napędowy z silnikami hydrostatycznymi zamontowanymi na osiach kół 1 - silnik spalinowy; 2 - pompa hydrostatyczna; 3 - silnik hydrostatyczny.

Biorąc pod uwagę możliwości pomp i silników hydrostatycznych można by było podjać próbę wprowadzenia napędów hydrostatycznych (dla autobusów jednoi dwuczłonowych) z wykorzystaniem takich urządzeń. W układach tych możliwe byłoby do zastosowania przekładnie osiowe przedstawiono na rys. 8 . a.

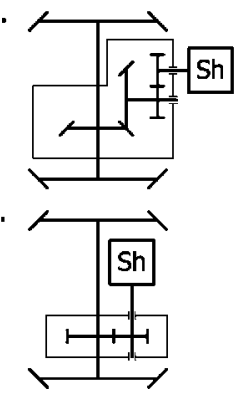

b.

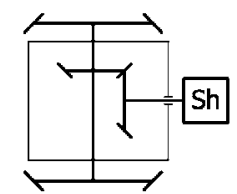

d.

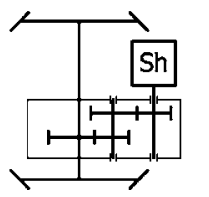

Rys. 8 -Układ przekładni osiowych $\mathrm{a}$-dwustopniowa (stożkowa i walcowa); b-jednostopniowa (stożkowa); c-jednostopniowa (walcowa); d-dwustopniowa (walcowa)

\section{Wstępny dobór urządzeń hydrostatycznych oraz określenie charakterystyki trakcyjnej}

Dla udowodnienia możliwości wykorzystania urządzeń hydrostatycznych w układzie napędowym typowego (eksploatowanego) autobusu szynowego przeprowadzono wstępną analizę i obliczenia symulacyjne dla następujących danych wyjściowych autobusu jednoczłonowego:

- masa własna / z pasażerami $47 / 57 \mathrm{Mg}$

- max. siła pociągowa $85 \mathrm{kN}$ 
- max. prędkość eksploatacyjna $120 \mathrm{~km} / \mathrm{h}$

- przełożenie przekładni $\leq 7$

- promień koła $920 \mathrm{~mm}$

- liczba osi $2 \div 4$

- moc silnika spalinowego $380 \div 400 \mathrm{~kW}$

- prędkość obrotowa silnika spalinowego $600 \div 2100 \mathrm{obr} / \mathrm{min}$.

Wyniki analizy wykazały, że istnieje możliwość realizacji napędu hydrostatycznego $\mathrm{z}$ wykorzystaniem dwóch pomp hydrostatycznych typu A4V6 175/40 o mocy 346,3 kW oraz czterech silników hydrostatycznych typu A6VM280/71 firmy Rexroth Bosch [12, 13].

Uzyskane parametry dla autobusu jednoczłonowego z wózkami dwuosiowymi przedstawiono $\mathrm{w}$ tabeli 1 , a charakterystykę trakcyjną na rys. 9.

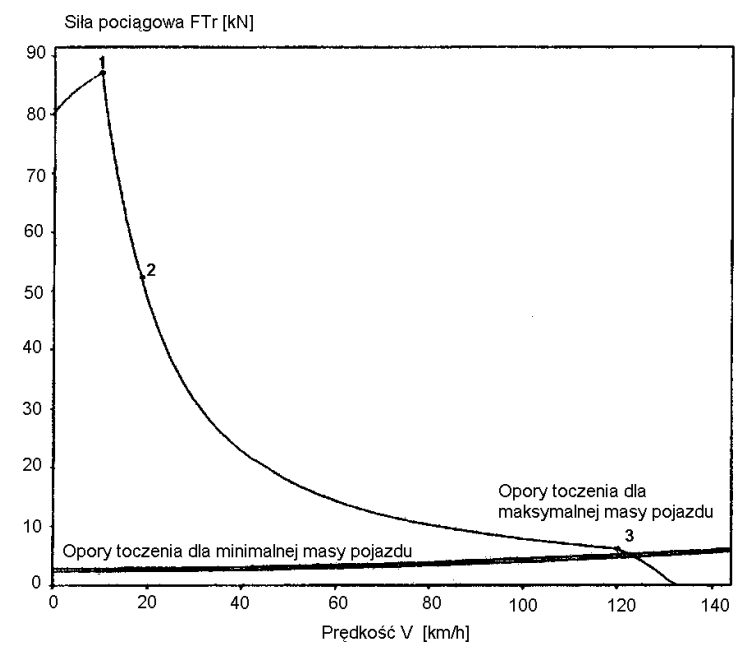

Rys. 9 - Charakterystyka trakcyjna autobusu szynowego jednoczłonowego z wózkami dwuosiowymi

Dobrane główne urządzenia hydrostatyczne układu napędowego przedstawiono na rys. 10 , a propozycje układu napędowego dla autobusu jednoczłonowego na rys. 11. a)

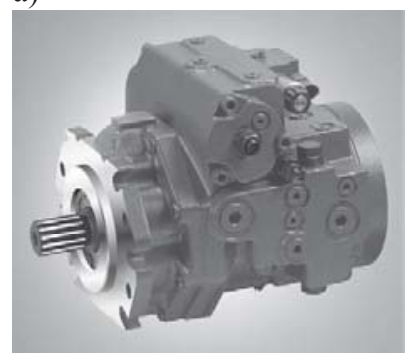

b)

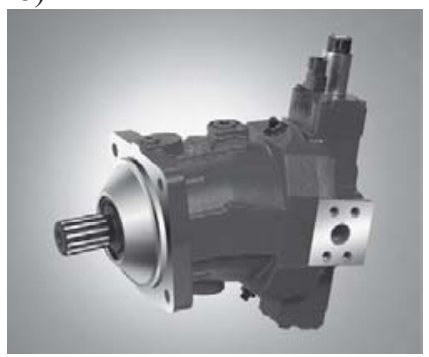

Rys. 10 - Główne urządzenia hydrostatyczne w proponowanym układzie napędowym hydrostatycznym a)- pompa hydrostatyczna typu A4VG 175/40 o mocy $364,3 \mathrm{~kW}$; b) - silnik hydrostatyczny A6WM280/71

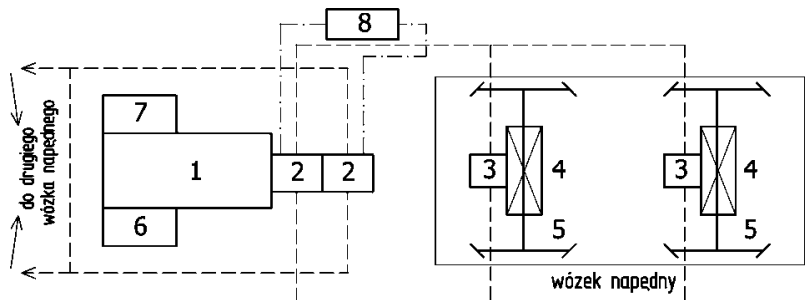

Rys. 11 - Propozycja układu napędowego autobusu szynowego jednoczłonowego $\mathrm{z}$ dwoma napędnymi wózkami dwuosiowymi :1 - silnik spalinowy; 2 - pompa hydrostatyczna; 3 - silnik hydrostatyczny; 4 - przekładnia osiowa; 5 - zestaw kołowy napędny; 6 prądnica (alternator); 7 - sprężarka; 8 - sterownik mikroprocesorowy

Dla autobusu szynowego dwuczłonowego proponujemy układ zdwojony przy czym moce pomp i silników hydrostatycznych będą dwukrotnie wyższe. Propozycję takiego układu napędowego $\mathrm{w}$ zastosowaniu do autobusu dwuczłonowego z dwoma dwuosiowymi wózkami napędowymi przedstawiono na rys. 12 .

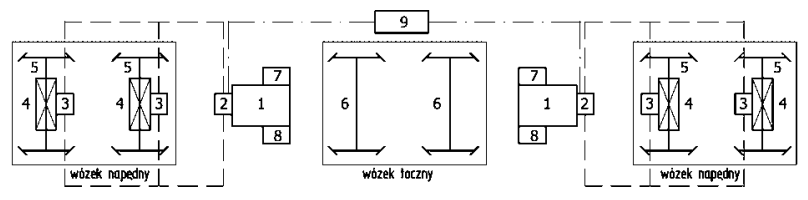

Rys. 12 - Propozycja układu napędowego autobusu szynowego jednoczłonowego z dwoma napędnymi wózkami dwuosiowymi 1 - silnik spalinowy; 2 - pompa hydrostatyczna; 3 - silnik hydrostatyczny; 4 - przekładnia osiowa; 5 - zestaw kołowy napędny; 6 zestaw kołowy toczny; 6 - prądnica (alternator); 8 - sprężarka; 9 - sterownik mikroprocesorowy

Nie należy również wykluczyć innych konfiguracji układów napędowych np. w zastosowaniu do autobusów szynowych wyposażonych w wózki jednoosiowe.

\section{Podsumowanie}

W pojazdach do przewozu pasażerów na liniach drugorzędnych wykorzystywane lekkie pojazdy szynowe (autobusy) wyposażone są najczęściej w przekładnie hydrauliczne, a następnie w przekładnie elektryczne, przy czym jednostką napędową pozostaje zawsze silnik spalinowy. Należy jednak zastanowić się nad innym rodzajem napędu wykorzystującego pompy i silniki hydrostatyczne. Byłoby to alternatywne rozwiązanie dla nowych rodzajów napędów, a jednocześnie uproszczenie układu w którym zastosowano by mniej skomplikowane i łatwiejsze w utrzymaniu urządzenia hydrostatyczne.

Ponadto uproszczeń należy się spodziewać w innych systemach i układach pojazdów takich jak np.: układy sterowania, hamulcowe oraz obniżenia wymagań $\mathrm{w}$ zakresie wytrzymałości konstrukcji, urządzeń pociągowo-zderznych oraz układów związanych z bezpieczeństwem ruchu i rejestracją parametrów pracy pojazdu. 
O wdrożeniu takich układów zarówno dla autobusów nowych jak i modernizowanych zdecyduje przede wszystkim rachunek ekonomiczny oraz zainteresowanie użytkowników takim rodzajem pojazdów do przewozu pasażerów.

\section{Literatura}

[1] Marciniak Z.: Propozycja układu napędowego dla krajowych autobusów szynowych do ruchu regionalnego Pojazdy Szynowe 2004, nr 2.

[2] Marciniak Z.: Układy napędowe lekkich pojazdów szynowych $z$ wykorzystaniem urzadzeń hydrostatycznych. Materiaty XIX Konferencji Naukowej „Pojazdy Szynowe” Targanice/k. Andrychowa, 2010.

[3] Marciniak Z., Medwid M.: Pojazdy szynowodrogowe. Wydawnictwo Ośrodka BadawczoRozwojowego Pojazdów Szynowych, Poznań, 1999.

[4] Medwid M., Przepióra K.: Pojazd szynowodrogowy do oczyszczania infrastruktury tramwajowej. Pojazdy Szynowe, 2003, nr 4.

[5] Pomierski W.: Hydrostatyczny napęd jazdy oraz roboczy pojazdu szynowo-drogowego do oczyszczania infrastruktury tramwajowej. Pojazdy Szynowe 2004, nr 3 i 4 .
[6] Pomierski W.: Analiza wybranych hydrostatycznych napędów jazdy pod katem ich własności trakcyjnych. Materiaty Seminarium Technicom 05, Gdańsk 2005.

[7] Pomierski W.: Hydrostatyczny napęd jazdy i robocze $w$ wybranych budowanych w kraju maszynach torowych. Materiaty Seminarium PPM-T Gdańsk, 2006.

[8] Dokumentacja techniczno-ruchowa pociagu sieciowego typu PS-00.M/B, PS-00.M/B-80-0. Materiały ZPS Stargard Szczeciński.

[9] Dokumentacja techniczno-ruchowa i instrukcja obstugi uniwersalnego ciagnika szynowego typu UCS-40.00. Materiały ZPS Stargard Szczeciński.

[10] Dokumentacja techniczno-ruchowa - Instrukcja obstugi wózka motorowego typu WM-15H.00, WM-15H.00-80-0. Materiaty ZPS Stargard Szczeciński.

[11] Dokumentacja techniczno-ruchowa - Instrukcja obstugi pojazdu utrzymania sieci i oświetlenia typu PUSiO.05, PUSiO.05-80-0. Materiały ZPS Stargard Szczecinski.

[12] Axial Piston Variable Pump A4VG. Katalog pomp hydrostatycznych firmy Rexroth Bosch.

[13] Axial Piston Variable Pump A4VM. Katalog silników hydrostatycznych formy Rexroth Bosch. 